This is an electronic reprint of the original article. This reprint may differ from the original in pagination and typographic detail.

Author(s): Böckerman, Petri; Hyytinen, Ari; Maczulskij, Terhi

Title: $\quad$ Alcohol Consumption and Long-Term Labor Market Outcomes

Year: $\quad 2017$

Version:

Please cite the original version:

Böckerman, P., Hyytinen, A., \& Maczulskij, T. (2017). Alcohol Consumption and LongTerm Labor Market Outcomes. Health Economics, 26(3), 275-291. https://doi.org/10.1002/hec.3290

All material supplied via JYX is protected by copyright and other intellectual property rights, and duplication or sale of all or part of any of the repository collections is not permitted, except that material may be duplicated by you for your research use or educational purposes in electronic or print form. You must obtain permission for any other use. Electronic or print copies may not be offered, whether for sale or otherwise to anyone who is not an authorised user. 


\title{
Alcohol consumption and long-term labor market outcomes
}

Petri Böckerman ${ }^{1}$, Ari Hyytinen ${ }^{2}$ and Terhi Maczulskij ${ }^{3}$

${ }^{1}$ Corresponding author. Turku School of Economics, Labour Institute for Economic Research and IZA. Address: Pitkänsillanranta 3A, FI-00530 Helsinki, Finland. Phone: +358-9-2535 7330. Fax: +358-9-2535 7332. E-mail: petri.bockerman@labour.fi

${ }^{2}$ Jyväskylä University School of Business and Economics, Jyväskylä, Finland. E-mail: ari.t.hyytinen@jyu.fi

${ }^{3}$ Labour Institute for Economic Research, Helsinki, Finland. E-mail: terhi.maczulskij@labour.fi

Declaration of interests: None

\begin{abstract}
This paper examines whether alcohol consumption is related to long-term labor market outcomes. We use twin data for Finnish men and women matched to register-based individual information on employment and earnings. The twin data allow us to account for the shared environmental and genetic factors. The quantity of alcohol consumption was measured by weekly average consumption using self-reported data from three surveys (1975, 1981 and 1990). The average of an individual's employment months and earnings were measured in adulthood over the period 1990-2009. The models that account for the shared environmental and genetic factors reveal that former drinkers and heavy drinkers both have almost $20 \%$ lower earnings compared to moderate drinkers. On average, former drinkers work annually c. 1 month less over the 20-year observation period. These associations are robust to the use of covariates, such as education, pre-existing health endowment and smoking.
\end{abstract}

KEYWORDS Alcohol consumption, binge drinking, employment, earnings, co-twin control 


\section{Health Economics, forthcoming}

\section{INTRODUCTION}

Alcohol is a commonly used drug worldwide. For example, an estimated 18 million adults in the United States have significant alcohol-related problems; $20 \%$ of men and $10 \%$ of women can be classified as heavy drinkers (U.S. Department of Health and Human Services, 2012). Alcohol misuse causes considerable health-related and other costs to the society.

There are two primary mechanisms through which (misuse of) alcohol may lead to undesirable labor market outcomes (e.g. Jones et al., 1995). First, it leads to increased absenteeism from work in the short run and to health problems in the long-run. Both of these erode people's ability to participate in the labor market and reduce their productivity at work (i.e. earnings capacity). Second, those who drink more heavily may face discrimination in the labour market. Table I provides a concise overview of the estimates for the relationship between alcohol consumption and labor market outcomes that have been presented in the literature. According to the US and Australian evidence, moderate alcohol consumers earn more than abstainers (French and Zarkin, 1995; Heien, 1996; Hamilton and Hamilton, 1997; Barrett, 2002) or abusers (Zarkin et al., 1998; Lee, 2003). However, the group of abstainers is heterogeneous in terms of drinking history as it contains also former drinkers who may experience serious problems in the labor market owing to their poorer health. Former drinkers are found to earn less than those who have never drunk (French and Zarkin, 1995; Heien, 1996). The quantity of alcohol consumption also matters: those US employees who consume c. 2-3 drinks per day have the highest earnings (French and Zarkin, 1995; Heien, 1996). Adolescent drinking is also negatively associated with adulthood earnings (Sloan and Grossman, 2011; Rose et al., 2014). 


\section{Health Economics, forthcoming}

How alcohol consumption is related to individuals' labor market attachment is a highly policy-relevant question. Being employed is, for example, an important determinant of a person's social status, having spillover effects on all aspects of wellbeing. The existing empirical results are mixed. The US studies do not find a negative association between drinking and employment (Mullahy and Sindelar, 1996; Feng et al., 2001), while the evidence from UK (MacDonald and Shields, 2001; 2004) and Finland (Johansson et al., 2007; Paijärvi et al., 2015) suggests that alcohol-dependent individuals have significantly weaker labor market attachment. Alcohol consumption is also positively related to sickness absence (Norström, 2006; Johansson et al., 2009).

[Table I here]

This paper explores the consequences of alcohol consumption for long-term labor market outcomes. We contribute to the debate in three major ways. First, the identification of the effect of alcohol consumption is challenging, because there are unobservable factors that are correlated with both alcohol consumption and the outcomes, such as labor market attachment and earnings. A consequence of this is that the Ordinary Least Squares (OLS) estimation does not produce an unbiased effect of alcohol consumption on the labor market outcomes. The twin data allow us to account both for shared environmental factors, such as family background, neighborhood and shared peer effects, as well as for genetic factors, such as risk, time and other preferences (van Dongen et al., 2012). Using data on non-identical (dizygotic, DZ) twins is the same as controlling for sibling effects, because DZ twins originate from the same family and neighborhood. As also ordinary siblings do, the DZ twins share $\sim 50 \%$ of the segregating genes. Using data on identical (monozygotic, MZ) twins allows us to further control for inherited traits and preferences, because two MZ twins are genetically identical. 


\section{Health Economics, forthcoming}

The use of MZ sample is important, because there is a substantial genetic component in the risk of alcoholism (Van Eerdewegh et al., 1998).

There are only two earlier empirical studies that have used twin data to estimate how alcohol consumption is associated with labor market outcomes (Lee, 2003; Rose et al., 2014). In the study that uses the Australian twin survey data (Lee, 2003), the author finds a wage premium for moderate drinkers. However, the income data of the survey are deficient. The study therefore uses the average cross-sectional earnings of the occupation in which the individuals are employed as the response variable. An analysis of the Finnish twin data examines the relationship between adolescent drinking and different adult outcomes, such as perceived financial difficulties (Rose et al., 2014). The data include no information on actual earnings, but the twins were asked to self-report their current financial situation ranking from 1 ('very good') to 5 ('very bad'). Adolescent drinking exacerbates marginally adulthood financial difficulties, even after controlling for the shared environmental and genetic effects.

The second reason why we can contribute to the debate is that our sample consists of twin pairs for whom we observe accurate administrative data on their prime working-age labor market attachment and earnings. Unlike the prior work, we can use the average of an individual's annual employment and earnings over the 20-year period. This is important, because cross-sectional measures are known to be inaccurate proxies for individuals' lifetime labor market attachment and earnings (Böhlmark and Lindquist, 2006; Haider and Solon, 2006). Moreover, using the register-based, long-term measures reduces measurement error due to non-response and reporting biases.

Third, we have access to relatively comprehensive information from three twin surveys that contain detailed, retrospective information on alcohol consumption. These data allow us examine whether the labor market outcomes among abstainers are heterogeneous in terms of their drinking history. In our empirical specifications former drinkers are distinguished from 


\section{Health Economics, forthcoming}

constant abstainers. To our knowledge, this distinction has not been made previously in studies that exploit twin data.

\section{METHODS}

\subsection{Data sources and the sample}

We use the Older Finnish Twin Cohort Study (of the Department of Public Health at the University of Helsinki). The twin data have been linked to the Finnish Longitudinal Employer-Employee Data (FLEED) of Statistics Finland. ${ }^{1}$ The Finnish Cohort Study was originally compiled from the Central Population Registry of Finland. Initial twin candidates were persons born before 1958 with the same birth date, commune of birth, sex, and surname at birth (Kaprio et al., 1979). Our twin data contain only same-sex twin pairs. The fact the initial twin candidates include only those twins who have the same surname reduces substantially the number of twins separated at birth in the final data. Langinvainio et al. (1981, p. 192) report that 51 twin pairs were separated at the age less than one year. This is only a very small share of the twin pairs in the original sample in 1975. A questionnaire was mailed to the candidates in 1975 to gather baseline data and to determine their zygosity. ${ }^{2}$ Two

\footnotetext{
${ }^{1}$ The twin cohort data linked to FLEED have been used in earlier studies (e.g. Hyytinen et al., 2013; Maczulskij, 2013). Prior studies can be consulted for details about the response rates, attrition and representativeness of the twin sample (Kaprio et al., 1979; see also Hyytinen et al., 2013; Maczulskij, 2013). Hyytinen et al. (2013, p. 63) and Maczulskij (2013, p. 95) provide evidence for the representativeness of the twin sample by comparing it to a one-third random sample of all Finns using FLEED and covering the same age cohorts.

${ }^{2}$ The zygosity was determined based on parents' responses on similarity of appearance in childhood. The classification was redone for a subsample of twins using 11 blood markers. These two classification methods produced almost identical results. The probability of misclassification of a blood marker concordant pair was only 1.7\% (Kaprio et al., 1979; see also Hyytinen et al., 2013).
} 


\section{Health Economics, forthcoming}

follow-up surveys were conducted in 1981 and 1990. The 1990 survey was sent only to those twins who were born after 1930 . The response rate for this latest survey was $77 \%$, giving us 12,502 twin pairs in total. Importantly for our purposes, all three twin surveys contained information on alcohol consumption.

Similarly to e.g. Hyytinen et al. (2013) and Maczulskij (2013), the twin data are linked to FLEED using personal identifiers. There are no misreported ID codes, which implies very good match. As has been reported in the earlier studies (e.g. Hyytinen et al., 2013), FLEED is an annual panel over the years 1990-2009 and covers the working-age population of Finland. We are thus able to track the labor market behavior of those twins who participated in the original twin surveys. FLEED is constructed from administrative registers on individuals, firms and establishments that are maintained by Statistics Finland. FLEED includes information on individuals' labor market status, and salaries and other sources of income, extracted from tax and other administrative registers. Thus, our employment and income data do not suffer from under-reporting or recall errors.

Our empirical analysis focuses on twin pairs for whom we observe information on alcohol consumption and subsequent earnings and employment. Excluding those men and women who are retired from the sample, ${ }^{3}$ our final estimation sample includes 3305 twin pairs, i.e., 6610 individuals. Table II provides descriptive statistics for our twin sample.

\footnotetext{
${ }^{3}$ Information on retirement is based on the exact labor market status during the last week of each year. Using a specific age restriction when forming the estimation sample would exclude some individuals who stay particularly long in the labor market. We do not want to impose such a restriction, because it could bias the estimates. If heavy drinkers are more likely to get sick and retire early, there is also a potential selection bias related to the exclusion of the retired from the estimation sample. We have estimated models in which we use the full sample without any restrictions regarding age or retirement status. Compared to the results that are reported in Table $\mathrm{V}$, the only difference is that in these re-estimated models we do not obtain statistically significant effects for heavy drinkers when using earnings as the outcome variable. All other results remain intact.
} 


\section{Health Economics, forthcoming}

[Table II here]

\subsection{Measures}

We use as our primary outcome variable employment months, calculated as the average number of employment months per year over the sample period of 1990-2009. Our second outcome variable is lifetime earnings. We measure them by the logarithm of the average of annual wage and salary earnings and self-employment income over the period of 1990-2009.

To quantify alcohol consumption, we derive a measure for weekly average consumption. The initial measure for alcohol consumption is the self-reported amount of alcohol consumed in 1975, 1981 and 1990. The twin survey gathered information on the frequency of alcohol consumption, measured by daily consumption per month, using a fivepoint scale ( 1 = 'never', 5 = 'over 16 days a month') and separately for different types of alcohol: beer, wine and spirits. The quantities of alcohol use were measured on a seven-point scale for each alcohol type, with the upper limits for consumption of more than 48 bottles of beer (10 bottles of wine) per week, or more than 20 bottles of spirits per month (Kaprio et al., 1987). A unit of alcohol is defined as 12 grams of pure alcohol. This information on alcohol consumption was converted into grams of pure alcohol consumed per week in 1990. In Finland 280 grams of pure alcohol per week (i.e. 24 units of alcohol) is commonly used limit of heavy drinking for men, and 190 grams per week (i.e. 16 units of alcohol) for women (Sillanaukee et al., 1992; Aalto, 2001; Salonsalmi et al., 2012).

The alcohol consumption was divided into four mutually exclusive categories: Former drinkers (those who were classified as abstainers in 1990, but did consume alcohol in 1975 


\section{Health Economics, forthcoming}

or/and 1981) ${ }^{4}$ Constant abstainers (those who were classified as abstainers in 1975, 1981 and 1990); Moderate drinkers (those who consumed alcohol in 1990, but less than 280 (190) grams per week); Heavy drinkers (those who consumed alcohol in 1990 more than 280 (190) grams per week).

We also have a measure for binge drinking. It is based on the question on pass out frequency during the past 12 months in the 1990 twin survey. Pass out frequency is zero for $87 \%$ of observations. For this reason, we used it as an indicator variable that obtains the value of one if the pass out frequency was positive (and otherwise it is zero).

We point out two things about our measures of alcohol consumption. First, the measures are predetermined for labor market outcomes. This is useful, because otherwise there might be a problem of simultaneity between alcohol consumption and labor market outcomes due to the positive income elasticity of alcohol consumption (Cawley and Ruhm, 2011). Second, according to Lemmens et al. (1988, 1992), heavy drinkers under-report while light drinkers tend to over-report their actual alcohol consumption. This means that the measured twindifference in alcohol consumption is smaller than the true difference for a twin pair in which one twin is a heavy drinker and the other is a lighter drinker. If this is true and if alcohol consumption is negatively associated with labor market outcomes (as the prior research summarized in Table I suggests), this kind of measurement error may lead, based on standard

\footnotetext{
${ }^{4}$ The sample size is not large enough so what we could divide the group of former drinkers into smaller subgroups. For example, only 32 individuals out of 424 can be classified as former heavy drinkers. The group of former drinkers is a mixture of different types of individuals making it difficult to separate the group further, because the decision to quit drinking is complex. It may, for example, be due to health-related reasons. A sick quitter may have stopped drinking alcohol due to a disease caused by the individual's alcohol drinking or due to a disease unrelated to it. His/her labor market outcomes are likely to have been negatively affected in either case. Also, the former alcoholics may have quit drinking without having a disease that causes them to quit. Drinkers may have stopped drinking for many other reasons, too.
} 


\section{Health Economics, forthcoming}

omitted variables reasoning, to an upward bias (i.e. estimates that are closer to zero). Our estimates of the effect of alcohol consumption on labor market outcomes are therefore likely to be conservative.

\subsection{Descriptive evidence}

Table III reports average employment months and lifetime earnings in euros, conditional on alcohol consumption. Compared to moderate drinkers, persons who are classified as heavy drinkers and former drinkers have significantly weaker labor market attachment and also lower lifetime earnings (Panel A). Among abstainers, those who are former drinkers have a particularly low level of earnings in comparison to the other groups. Binge drinkers have also a significantly weaker long-term labor market attachment and lower earnings (Panel B). The null hypothesis of equal group means is rejected for all measures in Panels A-B.

Figures 1-2 depict the employment months and average annual earnings by alcohol consumption status over the period of 1990-2009. It is important to note that these figures do not control for any differences between the individuals (i.e., between the former drinkers, constant abstainers, moderate drinkers or heavy drinkers). Year 1990 was a peak of an economic cycle, with low unemployment. In 1991-1994, Finland experienced a major economic crisis as GDP dropped sharply and unemployment increased to a record level. From 1995 onwards, a period of steady recovery followed, but unemployment declined only slowly. The economy developed relatively favorably until the financial crisis hit in 2008 .

As can be seen from Figure 1, labor market attachment is clearly strongest for those who are moderate drinkers and constant abstainers (Figure 1). Interestingly, employment for heavy drinkers has improved notably after 2000, as overall labor market conditions gradually 


\section{Health Economics, forthcoming}

improved. ${ }^{5}$ Although there was a general decrease in average earnings in each group during the economic depression of the early 1990s, the earnings gaps were already distinct in 1990 when we start measuring our labor market outcomes (Figure 2). The only exception is the group of heavy drinkers, whose earnings were at the same level with those of moderate drinkers in 1990. Their earnings dropped a lot in the economic crisis and have since then developed less favorably than the earnings of the other groups. The earnings gaps of the other groups remained quite stable relative to each other during the period 1990-2009. We can also see that there is annual variation in earnings. This implies that it is important to measure labor market outcomes over a longer time period.

Table IV documents a cross-tabulation of alcohol consumption patterns within twin pairs. There is a sufficient amount of within-twin pair variation in the data, which is necessary for identification. Roughly $24 \%$ of the observations in the four drinking behavior groups differ between the twins.

\section{[Tables III-IV and Figures 1-2 here]}

\subsection{Statistical methods}

Following e.g. Böckerman et al. (2015), we used four different types of regression analyses: First, we used OLS to regress our labor market measures on alcohol consumption for a combined sample of DZ and MZ twin individuals. Second, we took twin differences and reran the same regression using the same combined sample. In this twin-differenced model, all

\footnotetext{
${ }^{5}$ Paljärvi et al. (2015) show that individuals who had early limited drinking problems improve their employment considerably as they age, whereas those who had persistent drinking problems experience a constant decline in their employment.
} 


\section{Health Economics, forthcoming}

factors that two twins share (e.g. the shared environmental factors, business cycle effects and age) are eliminated. Third, we repeated the previous within-twin pair regression using the DZ sample. Finally, we ran the within-twin pair regression using the MZ sample. Both the shared environmental and genetic factors are differenced out in this last twin-differenced model. It is reasonable to assume that time-invariant risk and/or time preferences that affect alcohol consumption and labor market choices are at least partially genetically inherited. This implies they are better differenced out in the MZ sample than in the DZ sample.

\section{RESULTS}

\subsection{Main results - long-term labor market outcomes}

The estimates of alcohol consumption on average employment months are reported in Table V (Panel A). The baseline estimates using the standard OLS specification reveal that heavy drinkers have substantially weaker labor market attachment compared to moderate drinkers, i.e. heavy drinkers work, on average, c. 1.5 months less each year over the 20-year observation window ( $\beta=-1.47,95 \% \mathrm{CI}$ : -1.92 to -1.02$)$. Former drinkers have also weaker labor market attachment $(\beta=-0.60,95 \%$ CI: -0.98 to -0.21$)$. These results are in accordance with the earlier empirical studies described in Table I and the graphical illustration in Figure 1.

The results do not change much when we focus on the twin-differenced DZ-MZ model (column 2) and DZ model (column 3) that both control for the shared environment. These estimates show that being either a former drinker or a heavy drinker is associated with a decrease in average employment months of approximately $\sim 1$. The results for the MZ sample (column 4) confirm these findings even when both the shared environmental and genetic 


\section{Health Economics, forthcoming}

factors are controlled for. The estimates reveal that former drinkers and heavy drinkers work c. 0.9 months less each year over the 20 -year observation period.

The estimates of alcohol consumption on earnings are reported in Panel B of Table V. The baseline OLS estimates show that abstainers and heavy drinkers earn considerably less than moderate drinkers. The point estimates reveal that being either a constant abstainer or a former drinker is associated with a decrease in average annual earnings of $\sim 15-32 \%$. For heavy drinkers the earnings drop is even bigger, being $\sim 36 \%$. The results for the combined DZ-MZ sample (column 2) and DZ sample (column 3) confirm these findings. Finally, the within MZ twin-pair regressions (column 4) reveal that being a former drinker or a heavy drinker is negatively associated with subsequent earnings at the $10 \%$ significance level also when the genetic factors are accounted for (the estimate for former drinkers: $\beta=-0.20,95 \%$ CI: -0.41 to 0.01 , and for heavy drinkers: $\beta=-0.18,95 \%$ CI: -0.38 to 0.02 ). If taken literally, these results would imply that former drinkers and heavy drinkers earn c. $20 \%$ less each year compared to moderate drinkers over the 20-year period. The within MZ twin-pair regressions suggest that there is no longer statistically significant relation between being a constant abstainer and earnings. The negative relation in columns 1-3 may thus be related to genetic factors. ${ }^{6}$ The statistical insignificance in the smaller MZ sample is also driven by the smaller (absolute) point estimate.

We stratified our preferred twin-differenced models by gender to examine the potential gender heterogeneity in the associations (Table VI). The results for the combined sample of DZs and MZs show consistently that former drinkers and heavy drinkers have weaker labor

\footnotetext{
${ }^{6}$ The difference between DZ and MZ estimates suggest that factors related to genetic endowment are significantly correlated with the outcomes of interest and drinking patterns. If e.g. the risk and/or time preferences are to some degree genetically inherited, they are better differenced out in the MZ sample than in the DZ sample. It is worth pointing out here that the point estimates for DZs and MZs are not always statistically significantly different from each other.
} 


\section{Health Economics, forthcoming}

market attachment and lower earnings compared to moderate drinkers both among men and women. For example, women who are former drinkers work c. 1.5 months less each year. The only major difference compared to the estimates that use the pooled sample of men and women is that the earnings of constant abstainers are lower (than those of moderate drinkers) for women but not for men. The point estimates for former drinkers are larger for men. One reason for this may be that alcohol consumption has been at much higher level for men particularly among the older age cohorts. Former drinkers have generally weaker labor market outcomes even in the relatively small sample of MZs.

[Tables V-VI here]

\subsection{Robustness checks}

\section{Additional covariates}

The raw data suggest (cf. Figures 1-2) that most of the differences between former drinkers, constant abstainers, moderate drinkers and heavy drinkers may have already been present in 1990. Despite twin differencing, such differences between the groups suggest that omitted variable bias may be relevant. The baseline models did not include controls because many of the potential explanatory variables may not be predetermined. We therefore evaluate the robustness of our baseline results to the addition of various controls. We account for education, health-related controls, as well as past experiences of adverse shocks. These variables may contribute to labor market outcomes and be correlated with alcohol consumption. We use within twin pair variation in these variables to explore the robustness of our within twin estimations. 


\section{Health Economics, forthcoming}

Education is measured in years, based on the highest completed education level. We add education as a control, as there is a link between labor market success and alcohol use on the one hand, and alcohol use and labor market success on the other (Latvala et al., 2011). The health-related controls include the number of chronic diseases and smoking. The number of chronic diseases (as measured in the 1975 survey) is used to account for pre-existing health endowment. These diseases include, among others, emphysema, chronic obstructive pulmonary disease, high blood pressure, angina pectoris, peptic ulcer, diabetes, and gout. Smoking is measured using pack-years in 1990. It captures lifetime consumption of cigarettes. We add smoking behavior as a control, because there is evidence that alcohol and cigarette consumption are jointly determined (Van Ours, 2004). We also include a stressful life events (SLE) index that is a weighted sum of 11 negative life shocks selected from the 17 Holmes and Rahe items (Riese et al., 2013), taken from the 1990 twin survey. Adverse life shocks may cause one twin to consume alcohol and also contribute to his/her weaker labor market attachment and lower earnings.

The results that account for the controls are shown in Table VII. While not reported in detail, education obtains a positive coefficient $(\beta=0.06,95 \% \mathrm{CI}: 0.02$ to 0.09$)$ and the number of diseases obtains a negative coefficient $(\beta=-0.07,95 \%$ CI: -0.13 to -0.02$)$ when long-term earnings are used as the outcome variable. These findings indicate that educational attainment and pre-existing health endowment are important predictors of lifetime labor market success. The SLE index has a negative relationship with labor market attachment. The results for alcohol consumption remain largely unchanged. The only exception is the coefficient of heavy drinkers which, while still negative, is no longer statistically significant at the conventional level in a model that uses employment as the outcome variable. Being a former drinker seems to be negatively associated with earnings $(\beta=-0.21,95 \%$ CI: -0.42 to 0.002) and labor market attachment $(\beta=-0.93,95 \% \mathrm{CI}$ : -1.71 to -0.15$)$. Being a heavy drinker 


\section{Health Economics, forthcoming}

is also negatively associated with earnings at the $10 \%$ level $(\beta=-0.17,95 \%$ CI: -0.37 to 0.03$)$. While our earlier qualitative conclusions were supported, these results have to be treated with some caution, because educational attainment, smoking and SLE index are not likely to be completely predetermined (i.e. they are potentially 'bad' controls, because past drinking, as measured in 1975 and 1981, may affect them).

\section{[Tables VII here]}

\section{Alternative measures for alcohol consumption}

We constructed three alternative measures for alcohol consumption and used them to reestimate the MZ twin-differenced models for average employment months and earnings. The results are shown in Table VIII. First, following Aalto and Seppä (2002), we used alternative thresholds for heavy drinking. In a survey study, Sillanaukee et al., (1992) examined the views of general practitioners about how they advise their patients about the maximum and yet appropriate levels of alcohol consumption. The mean levels were 15.5 drinks per week for men and 11 for women. These levels are about two-thirds of the standard Finnish threshold values for heavy drinking that we have used so far. Because one drink unit corresponds 12 grams of pure alcohol, we can use these numbers to construct alternative thresholds for heavy drinking. Using 186 grams per week for men and 132 grams for women as the threshold levels, we found that our main findings are supported. The only exception is that the coefficient for heavy drinkers is statistically insignificant when employment is used as the response variable.

Second, we considered binge drinking, because it is a common form of alcohol misuse and because it has been documented to cause significant negative health effects (Wen et al., 2012). Binge drinkers appear to have weaker labor market attachment later in life even when 


\section{Health Economics, forthcoming}

the relatively small sample of MZs is used ( $\beta=-0.80,95 \% \mathrm{CI}:-1.32$ to -0.28$)$. Thus, those who are binge drinkers have, on average over the 20-year period, 0.8 fewer employment months each year. They also have c. $10 \%$ lower earnings compared to non-binge drinkers.

Third, we added binge drinking to the regression models together with our categorical alcohol consumption measures. The results for former drinkers remain intact. However, the coefficients for heavy drinkers are statistically insignificant when both employment and earnings are used as the response variable. These results show that the negative labor market effects of heavy drinking are most likely related to binge drinking behavior. Binge drinking itself remains negatively associated with labor market attachment $(\beta=-0.75,95 \% \mathrm{CI}:-1.74$ to $-0.19)$.

[Tables VIII here]

\section{Alternative income measure}

As a further robustness test, we considered an alternative measure for lifetime earnings. To this end, we calculated a measure for lifetime income as the logarithm of the average of annual taxable income over the period of 1990-2009. This measure is broader than earnings as it also includes capital income (dividends, capital gains) and income transfers and social security benefits, such as unemployment and parental leave benefits. When the response variable was lifetime income, our result for former drinkers remains intact, although the (absolute) size of the coefficient was slightly smaller. Being a former drinker is associated with $15 \%$ lower lifetime income in the combined DZ/MZ sample $(\beta=-0.148, \mathrm{p}=0.020,95 \%$ CI: -0.274 to -0.023 ). The corresponding estimate for earnings is $-28 \%$ (Table V). The coefficients for heavy drinkers became statistically insignificant. These findings are not a sign 


\section{Health Economics, forthcoming}

of sensitivity of our results, as there is an obvious explanation for them. Income transfers and social security benefits may protect former and heavy drinkers from the adverse labor market consequences of alcohol consumption. Moreover, capital income is not similarly affected by

e.g. poorer health that excessive alcohol consumption may cause. There is also earlier evidence that shows that the effect of risky behavior in the form of smoking on the taxable income is smaller (as compared to earnings; see Böckerman et al., 2015). These patterns are consistent with the view that the social safety net of the (Finnish) welfare state protects people from the adverse impacts of exogenous shocks and from people's own harmful choices.

\section{Sign error}

Finally, inspired by the recent work of Gelman and Carlin (2014), we considered the risk of making a sign error ("Type S error") or exaggerating the effect size ("Type M error"). The intuition of Type $\mathrm{S}$ error is that it measures the probability that our estimate has the incorrect sign, given that it is found to be statistically significant. Type $M$ error, in turn, refers to the factor by which the effect could in expectation be overestimated, given that it is statistically significant; for a more detailed discussion, see Gelman and Carlin (2014).

To evaluate these errors, we have to hypothesize a true effect size. It seems that there is no such prior information for the long-term employment or earnings effects. We therefore straightforwardly consider the possibility that the true effect size is $25 \%$ smaller in absolute value than what our preferred point estimates suggest: Using the regressions for employment months and the estimate (and its standard error) for the former drinkers from the twindifferenced DZ-MZ model (of Table V), we find that Type S error is far less than 0.01. Thus, it seems that the probability that our estimate has the incorrect sign, given that it is statistically significant, is negligible. We also find that Type $\mathrm{M}$ error for the same point estimate is 1.19 . 


\section{Health Economics, forthcoming}

This indicates that, in expectation, the estimated effect is $\sim 1.2$ times too high, given that it is found to be statistically significant and what we hypothesized about the true effect size. When the response variable is earnings and the estimate and its standard error for the former drinkers is taken from the estimated twin-differenced MZ model (of Table V), these numbers are $<0.01$ and 1.85, respectively. Even in this smaller sample, these numbers seem satisfactory if they are compared to what Gelman and Carlin (2014) consider problematic.

\section{DISCUSSION}

This paper used twin data linked to register-based individual information to examine the longterm relationship between alcohol consumption and lifetime labor market outcomes. Our results show that former drinkers and heavy drinkers both have almost $20 \%$ lower earnings compared to moderate drinkers. Former drinkers also work c. 1 month less each year over the 20-year observation period. These negative associations remained statistically significant when the shared environmental and genetic factors were controlled for. Because many of the differences examined may have been present already at the beginning of our observation window, we estimated models with additional controls. The negative associations for the former drinkers were also robust to the use of various covariates, such as education, preexisting health endowment and smoking. We also find that binge drinking, a popular form of alcohol misuse, is negatively associated with subsequent employment months and may in fact be the reason why heavy drinking is associated with subsequent adverse labor market outcomes.

We examined the labor market consequences of alcohol consumption in the Finnish context. As in many other countries, alcohol consumption has severe negative health consequences (including morbidity and mortality) in Finland. Alcohol-related mortality 


\section{Health Economics, forthcoming}

increased by $16 \%$ among men and by $31 \%$ among women over the period 2004-2005 after a large reduction in the price of alcohol in 2004 (Herttua et al., 2008). As a result, alcohol killed more Finns aged 15-64 years than cardiovascular disease or cancer did in 2005 (Statistics Finland, 2006). Our findings complete these prior findings by showing how alcohol use is associated with long-term labor market outcomes. We are inclined to think that these findings of ours generalize to other developed European countries.

There are some issues that have to be taken into account when interpreting our estimates. First, if heavy drinking increases considerably the probability of dying and/or attrition in our observation window, the estimates for heavy drinkers could be downward biased. However, this bias should be relatively minor in our context, because it takes a long time before serious alcohol-related diseases appear. In addition, for an individual not to be included in our analyses, it would have required that he or she was not employed and/or earned anything over the period 1990-2009 that constitutes the prime working age. The earlier analyses of the Finnish twin data (that we use) have also generally not found significant nonrandom selection (Kaprio, 2013). ${ }^{7}$

Second, we are not able account for the fact that people may change their drinking status after 1990. Some heavy drinkers may become former drinkers or moderate drinkers over time. For example, employment of heavy drinkers may start to increase towards the end of our observation period because some of them quit drinking.

Third, we stress that our analysis of twin data does not completely rule out non-causal explanations for the negative association between alcohol consumption and labor market outcomes later in life. For example, a confounding psychological factor may induce one twin to consume alcohol. This unmeasured characteristic may also be significantly related to labor

\footnotetext{
${ }^{7}$ There is earlier evidence from other countries that alcohol use is not significantly associated with attrition in panel data (Cunradi et al., 2005).
} 


\section{Health Economics, forthcoming}

market success. This means that both alcohol consumption and long-term labor market outcomes may be driven by it.

Fourth, it is possible that there are significant peer effects in alcohol consumption at twin pair level. There are earlier empirical studies that have used twin data to study peer effects (e.g. Harden et al., 2008). These studies use information on siblings' best friends and their behavior. Unfortunately, the twin data that we use do not have such information peers' alcohol consumption. We can, however, conclude that the negative associations between being a former drinker or a heavy drinker and the long-term labor market outcomes are not caused by the shared environmental and genetic factors.

We conclude by noting that to establish the exact conditions under which alcohol consumption is rational and whether consumers of addictive goods behave rationally or not is difficult (Cawley and Ruhm, 2011). There is arguably less scope for heavy alcohol consumption to be based on rational reasoning (with stable preferences), if alcohol consumption is associated both with significant out-of-pocket consumption costs and negative physical and mental health effects. Our findings suggest that former drinkers suffer nonnegligible indirect monetary costs in terms of lost labor market earnings. Whether consumers are capable of taking into account the impact of their current alcohol consumption on their future labor market attachment and earnings capacity - and that such impact persists even after they quit drinking - is an open question.

\section{ACKNOWLEDGEMENTS}

This research has been financially supported by the Jenny and Antti Wihuri Foundation. We would like to thank Jaakko Kaprio for comments and access to the twin data. We are also grateful to two anonymous referees and Jutta Viinikainen for valuable comments that have greatly improved the paper. 


\section{REFERENCES}

Aalto M. 2001. Prevalence and brief intervention of heavy drinkers in primary health care. Lahti Project Study. Acta Universitatis Tamperensis 802: Tampere.

Aalto M, Seppä K. 2002. At which level to advise a patient? General practitioners' view. Alcohol \& Alcoholism 36: 431-433.

Barrett G. 2002. The effect of alcohol consumption on earnings. Economic Record 78: 7996.

Böckerman P, Hyytinen A, Kaprio J. 2015. Smoking and long-term labour market outomes. Tobacco Control 24: 348-353.

Böhlmark A, Lindquist MJ. 2006. Life-cycle variations in the association between current and lifetime income: replication and extension for Sweden. Journal of Labor Economics 24: 879-900.

Cunradi CB, Moore R, Killoran M, Ames G. 2005. Survey nonresponse bias among young adults: the role of alcohol, tobacco, and drugs. Substance Use \& Misuse 40: 171-185. 


\section{Health Economics, forthcoming}

Cawley J, Ruhm CJ. 2011. The economics of risky health behaviors. In Handbook of Health Economics, Volume 2, Pauly MV, Mcguire TG, Barros PP (eds). Elsevier: New York, pp. 95-199.

van Dongen J, Slagboom PE, Draisma HH, et al., 2012. The continuing value of twin studies in the omics era. Nature Reviews Genetics 13: 640-653.

Van Eerdewegh P, Foroud T, Hesselbrock V, et al. (1998). Genome-wide search for genes affecting the risk for alcohol dependence. American Journal of Medical Genetics (Neuropsychiatric Genetics) 81: 207-215.

Feng W, Zhou W, Butler JS, Booth B, French M. 2001. The impact of problem drinking on employment. Health Economics 10: 509-521.

French M, Zarkin G. 1995. Is moderate alcohol use related to wages? Evidence from four worksites. Journal of Health Economics 14: 319-344.

Gelman A, Carlin J. 2014. Beyond power calculations: assessing Type S (sign) and Type M (magnitude) errors. Perspectives in Psychological Science 9: 610-611.

Haider S, Solon G. 2006. Life-cycle variation in the association between current and lifetime earnings. American Economic Review 96: 1308-1320.

Hamilton V, Hamilton B. 1997. Alcohol and earnings: does drinking yield a wage premium? Canadian Journal of Economics 30: 135-151. 
Harden KP, Hill JE, Turkheimer E, Emery RE. 2008. Gene-environment correlation and interaction in peer effects on adolescent alcohol and tobacco use. Behavior Genetics 38: $339-347$.

Heien D. 1996. The relationship between alcohol consumption and earnings. Journal of Studies on Alcohol and Drugs 57: 536-542.

Herttua K, Mäkelä P, Martikainen P. 2008. Changes in alcohol-related mortality and its socioeconomic differences after a large reduction in alcohol prices: a natural experiment based on register data. American Journal of Epidemiology 168: 1110-1118.

Hyytinen A, Ilmakunnas P, Toivanen O. 2013. The return-to-entrepreneurship puzzle. Labour Economics 20: 57-67.

Johansson E, Alho H, Kiiskinen U, Poikolainen K. 2007. The association of alcohol dependency with employment probability: evidence from the population survey 'Health 2000 in Finland'. Health Economics 16: 739-754.

Johansson E, Böckerman P, Uutela A. 2009. Alcohol consumption and sickness absence: evidence from microdata. European Journal of Public Health 19: 19-22.

Jones S, Casswell S, Zhang J-F. 1995. The economic costs of alcohol-related absenteeism and reduced productivity among the working population of New Zealand. Addiction 90: $1455-1461$. 
Kaprio J, Artimo M, Sarna S, Rantasalo I. 1979. The Finnish twin registry: baseline characteristics. Section I: materials methods, representativeness and results for variables special to twin studies. Department of Public Health, Publications, M(47): Helsinki.

Kaprio J, Koskenvuo M, Langinvainio H, Romanov K, Sarna S, Rose R. 1987. Genetic influences on use and abuse of alcohol: a study of 5638 adult Finnish twin brothers. Alcoholism: Clinical and Experimental Research 11: 349-356.

Kaprio J. 2013. The Finnish twin cohort study: an update. Twin Research and Human Genetics 8: 1-6.

Langinvainio H, Koskenvuo M, Kaprio J, Lönnqvist J, Tarkkonen L. 1981. Finnish twins reared apart: preliminary characterization of rearing environment. Progress in Clinical and Biological Research 69: 189-198.

Latvala A, Dick D, Tuulio-Henriksson A, Suvisaari J, Viken R, Rose R, et al., 2011. Genetic correlation and gene-environment interaction between alcohol problems and educational level in young adulthood. Journal of Studies on Alcohol and Drugs 72: 210-220.

Lee YL. 2003. Wage effects of drinking in Australia. Australian Economic Review 36: 265282.

Lemmens P, Tan ES, Knibbe RA. 1988. Bias due to non-response in a Dutch survey on alcohol consumption. Addiction 86: 1069-1077. 
Lemmens P, Tan ES, Knibbe RA. 1992. Measuring quantity and frequency of drinking in a general population survey: a comparison of five indices. Journal of Studies on Alcohol and Drugs 53: 476-486.

MacDonald Z, Shields M. 2001. The impact of alcohol consumption on occupational attainment in England. Economica 68: 427-453.

MacDonald Z, Shields M. 2004. Does problem drinking affect employment? Evidence from England. Health Economics 13: 139-155.

Maczulskij T. 2013. Employment sector and pay gaps: genetic and environmental influences. Labour Economics 23: 89-96.

Norström T. 2006. Per capita alcohol consumption and sickness absence. Addiction 101: $1421-1427$.

Mullah J, Sindelar J. 1996. Employment, unemployment, and problem drinking. Journal Health Economics 15: 409-434.

van Ours JC. 2004. A pint a day raises a man's pay; but smoking blows that gain away. Journal of Health Economics 23: 863-886.

Paljärvi T, Martikainen P, Pensola T, Leinonen T, Herttua K, Mäkelä P. 2015. Life cource trajectories of labour market participation among young adults who experienced severe 


\section{Health Economics, forthcoming}

alcohol-related health outcomes: a retrospective cohort study. PLoS ONE 10(5): $\mathrm{e} 0126215$.

Riese H, Snieder H, Jeronimus B, Korhonen T, Rose R, Kaprio J, Ormel J. 2013. Timing of stressful life-events affects stability and change of Neuroticism. European Journal of Personality 28: 193-200.

Rose R, Winter T, Viken R, Kaprio J. 2014. Adolescent alcohol abuse and adverse adult outcomes: evaluating confounds with drinking-discordant twins. Alcoholism: Clinical and Experimental Research 38: 2314-2321.

Salonsalmi A, Laaksonen M, Lahelma E, Rahkonen O. 2012. Drinking habits and disability retirement. Addiction 107: 2128-2136.

Sillanaukee P, Kiianmaa K, Roine R, Seppä K. 1992. Alkoholin suurkulutuksen kriteerit (Criteria of heavy drinking). Finnish Medical Journal 47: 2919-2921.

Sloan F, Grossman D. 2011. Alcohol consumption in early adulthood and schooling completed and labor market outcomes at midlife by race and gender. American Journal of Public Health 101: 2093-2101.

Staiger D, Stock JH. 1997. Instrumental variables regression with weak instruments. Econometrica 65: 447-486.

Statistics Finland. 2006. Kuolemansyyt 2005. Statistics Finland: Helsinki. 
U.S. Department of Health and Human Services. 2012. Results from the 2011 National Survey on Drug Use and Health: Summary of National Findings. U.S. Department of Health and Human Services: Washington DC. Available from: http://www.samhsa.gov/data/nsduh/2k11results/nsduhresults2011.htm

Wen XJ, Kanny D, Thompson WW, Okoro CA, Town M, Balluz LS. 2012. Binge drinking intensity and health-related quality of life among US adult binge drinkers. Preventing Chronic Disease 9, E86.

Zarkin G, French M, Mroz T, Bray J. 1998. Alcohol use and wages: new results from the National Household Survey on Drug Abuse. Journal of Health Economics 17: 53-68. 
Figures and tables

Figure 1. Average employment months by alcohol consumption status over the period 19902009

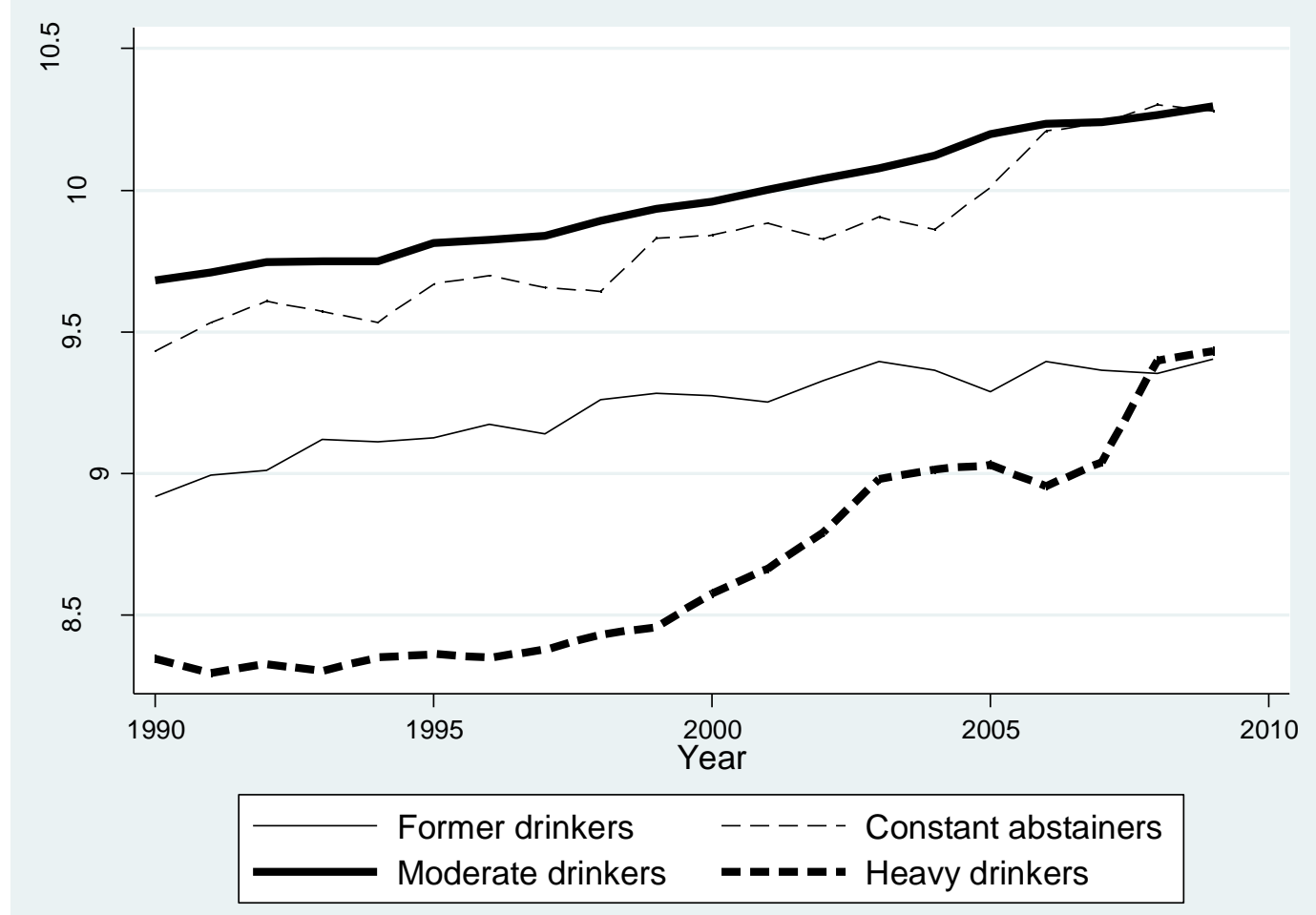


Figure 2. Average annual earnings by alcohol consumption status over the period 1990-2009.

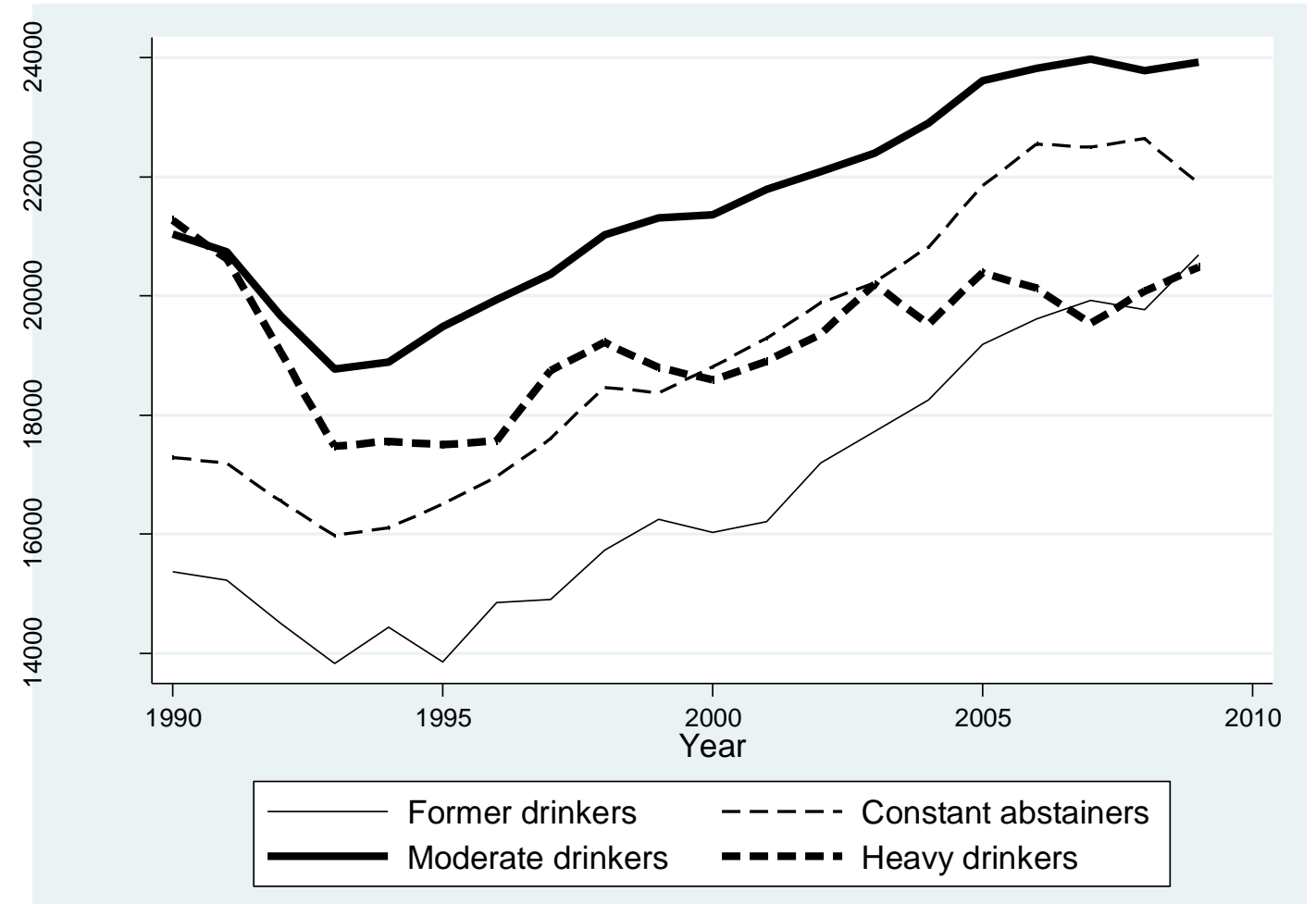

Notes: Earnings are deflated using the consumer price index (base year 2000). 
Health Economics, forthcoming

Table I. Summary of previous research

\begin{tabular}{|c|c|c|c|c|c|}
\hline $\begin{array}{l}\text { Author(s) and } \\
\text { publication } \\
\text { year }\end{array}$ & Data & Outcome & Alcohol measure & Methods & Main findings \\
\hline $\begin{array}{l}\text { French, M. and } \\
\text { Zarkin, G. } \\
1995 .\end{array}$ & $\begin{array}{l}\text { A sample of } \\
\text { randomly selected } \\
\text { employees at four US } \\
\text { worksites in } 1991 \text {, } \\
1992 \text { and } 1993\end{array}$ & Weekly wages & $\begin{array}{l}\text { Dummy variables for } \\
\text { former drinkers and for } \\
\text { those who have never } \\
\text { drunk. An estimate of the } \\
\text { number of drinks } \\
\text { consumed in the past } 30 \\
\text { days. }\end{array}$ & OLS & $\begin{array}{l}\text { Moderate alcohol users have higher } \\
\text { wages than abstainers and heavy } \\
\text { drinkers. Those who drink c. } 2-3 \\
\text { drink per day have the highest } \\
\text { wages. }\end{array}$ \\
\hline Heien, D. 1996. & $\begin{array}{l}\text { National Household } \\
\text { Survey on Alcohol } \\
\text { Use from } 1979 \text { and } \\
1984 \text { and Quality of } \\
\text { Employment Survey } \\
\text { from } 1972-73\end{array}$ & $\begin{array}{l}\text { Annual earnings } \\
\text { and weekly } \\
\text { wage }\end{array}$ & $\begin{array}{l}\text { A dummy variable for } \\
\text { former drinkers and } \\
\text { polynomial of the number } \\
\text { of drinks consumed per } \\
\text { month. }\end{array}$ & OLS & $\begin{array}{l}\text { Moderate alcohol users have higher } \\
\text { wages than abstainers and heavy } \\
\text { drinkers. Former drinkers earn less } \\
\text { than those who have never drunk. } \\
\text { Income level is highest for those } \\
\text { who consume 2-3 drinks per day. }\end{array}$ \\
\hline $\begin{array}{l}\text { Mullahy, J. and } \\
\text { Sindelar, J. } \\
1996 .\end{array}$ & $\begin{array}{l}\text { Alcohol Supplement } \\
\text { of the National Health } \\
\text { Interview Survey in } \\
1988\end{array}$ & $\begin{array}{l}\text { Dummy } \\
\text { variables for } \\
\text { unemployment } \\
\text { and } \\
\text { employment }\end{array}$ & $\begin{array}{l}\text { Ethanol consumption, a } \\
\text { dummy for diagnosed } \\
\text { alcohol abuse and two } \\
\text { dummies for heavy } \\
\text { drinking pattern. }\end{array}$ & OLS and IV & $\begin{array}{l}\text { Problem drinking results in reduced } \\
\text { employment and increased } \\
\text { unemployment, but the impacts } \\
\text { were statistically insignificant. }\end{array}$ \\
\hline $\begin{array}{l}\text { Hamilton, V. } \\
\text { and Hamilton, } \\
\text { B. } 1997 .\end{array}$ & $\begin{array}{l}\text { General Social } \\
\text { Survey data from } \\
1985\end{array}$ & Annual income & $\begin{array}{l}3 \text { categories: non-drinkers, } \\
\text { moderate drinkers and } \\
\text { heavy drinkers calculated } \\
\text { using frequencies and } \\
\text { quantities of alcohol } \\
\text { consumed. }\end{array}$ & $\begin{array}{l}\text { OLS, } \\
\text { selectivity- } \\
\text { corrected } \\
\text { regression }\end{array}$ & $\begin{array}{l}\text { Moderate alcohol users have higher } \\
\text { wages than abstainers and heavy } \\
\text { drinkers. }\end{array}$ \\
\hline $\begin{array}{l}\text { Zarkin, G., } \\
\text { French, M., } \\
\text { Mroz, T. and } \\
\text { Bray, J. } 1998 .\end{array}$ & $\begin{array}{l}\text { National Household } \\
\text { Surveys on Drug } \\
\text { Abuse in } 1991 \text { and } \\
1992\end{array}$ & Hourly wages & $\begin{array}{l}8 \text { categories: non-drinkers, } \\
2 \text { light drinker categories, } \\
3 \text { moderate drinker } \\
\text { categories and } 2 \text { heavy } \\
\text { drinker categories. } \\
\text { Calculated using the } \\
\text { estimates of number of } \\
\text { drinks consumed during } \\
\text { the past } 30 \text { days. }\end{array}$ & OLS & $\begin{array}{l}\text { Moderate alcohol users have higher } \\
\text { wages than abstainers. }\end{array}$ \\
\hline
\end{tabular}




\section{Health Economics, forthcoming}

\begin{tabular}{|c|c|c|c|c|c|}
\hline $\begin{array}{l}\text { MacDonald, Z. } \\
\text { and Shields, M. } \\
2001 .\end{array}$ & $\begin{array}{l}\text { Health Survey for } \\
\text { England }\end{array}$ & $\begin{array}{l}\text { Occupational } \\
\text { ranking, } \\
\text { measured as the } \\
\text { average } \\
\text { earnings of } \\
\text { individual's } \\
\text { occupation. }\end{array}$ & $\begin{array}{l}\text { Drinking intensity and } \\
\text { drinking frequency over } \\
\text { the last } 12 \text { months. }\end{array}$ & $\begin{array}{l}\text { IV- } \\
\text { regression } \\
\text { analysis }\end{array}$ & $\begin{array}{l}\text { Moderate alcohol users have higher } \\
\text { labor market attachment than heavy } \\
\text { users. }\end{array}$ \\
\hline $\begin{array}{l}\text { Feng, E., Zhou, } \\
\text { W., Butler, J.S., } \\
\text { Booth, B., and } \\
\text { French, M. } \\
2001 .\end{array}$ & $\begin{array}{l}\text { A random sample of } \\
\text { working age } \\
\text { population from six } \\
\text { Southern states in the } \\
\text { US }\end{array}$ & $\begin{array}{l}\text { A dummy } \\
\text { variable for ever } \\
\text { working in the } \\
\text { past year }\end{array}$ & $\begin{array}{l}\text { A dummy for problem } \\
\text { drinker. }\end{array}$ & $\begin{array}{l}\text { Univariate } \\
\text { probit model }\end{array}$ & $\begin{array}{l}\text { No negative association between } \\
\text { problem drinking and employment. }\end{array}$ \\
\hline $\begin{array}{l}\text { Barrett, G. } \\
2002 .\end{array}$ & $\begin{array}{l}\text { Australian National } \\
\text { Health Survey 1989- } \\
90\end{array}$ & $\begin{array}{l}\text { Annual income } \\
\text { prior the survey } \\
\text { year }\end{array}$ & $\begin{array}{l}3 \text { categories: non-drinkers, } \\
\text { moderate drinkers and } \\
\text { heavy drinkers calculated } \\
\text { using frequencies and } \\
\text { quantities of alcohol } \\
\text { consumed. }\end{array}$ & $\begin{array}{l}\text { Selectivity- } \\
\text { corrected } \\
\text { regression }\end{array}$ & $\begin{array}{l}\text { Moderate alcohol users have higher } \\
\text { wages than abstainers and heavy } \\
\text { drinkers. }\end{array}$ \\
\hline $\begin{array}{l}\text { Lee, Y. L. } \\
2003 .\end{array}$ & $\begin{array}{l}\text { Australian Twin } \\
\text { Registry mostly from } \\
\text { the } 1988-89 \text {. }\end{array}$ & $\begin{array}{l}\text { Mean earnings } \\
\text { of the person's } \\
\text { occupation }\end{array}$ & $\begin{array}{l}3 \text { categories: non-drinkers, } \\
\text { light drinkers and } \\
\text { moderate drinkers } \\
\text { calculated from } \\
\text { frequencies and quantities } \\
\text { of alcohol consumed. }\end{array}$ & $\begin{array}{l}\text { OLS and } \\
\text { twin } \\
\text { differencing }\end{array}$ & $\begin{array}{l}\text { A positive wage premium for } \\
\text { moderate drinking. }\end{array}$ \\
\hline $\begin{array}{l}\text { MacDonald, Z. } \\
\text { and Shields, M. } \\
2004 .\end{array}$ & $\begin{array}{l}\text { Health Survey for } \\
\text { England }\end{array}$ & $\begin{array}{l}\text { A dummy } \\
\text { variable for } \\
\text { working status }\end{array}$ & $\begin{array}{l}\text { Psychological and physical } \\
\text { symptoms of drinking, a } \\
\text { dummy for drinking every } \\
\text { day and a dummy for } \\
\text { drinking more than } 45.3 \\
\text { units per week. }\end{array}$ & $\begin{array}{l}\text { Univariate } \\
\text { and bivariate } \\
\text { probit and } \\
\text { IV-Probit } \\
\text { models. }\end{array}$ & $\begin{array}{l}\text { Problem drinking results in lower } \\
\text { probability of working. }\end{array}$ \\
\hline $\begin{array}{l}\text { Norström, T. } \\
2006 .\end{array}$ & $\begin{array}{l}\text { Macro data issued by } \\
\text { the Statistics Sweden }\end{array}$ & $\begin{array}{l}\text { Sickness } \\
\text { absence rate or } \\
\text { the number of } \\
\text { illnesses } \\
\text { recorded per } \\
\text { insured person }\end{array}$ & $\begin{array}{l}\text { Sales of liters of } 100 \% \\
\text { alcohol per inhabitant. }\end{array}$ & OLS & $\begin{array}{l}\text { An increase in per capita alcohol } \\
\text { consumption is associated with an } \\
\text { increase in sickness absence for } \\
\text { men. }\end{array}$ \\
\hline
\end{tabular}




\section{Health Economics, forthcoming}

\begin{tabular}{|c|c|c|c|c|c|}
\hline $\begin{array}{l}\text { Johansson, E., } \\
\text { Alho, H., } \\
\text { Kiiskinen, U. } \\
\text { and } \\
\text { Poikolainen, K. } \\
2007 .\end{array}$ & $\begin{array}{l}\text { Finnish 'Health } 2000 \text { ' } \\
\text { population survey }\end{array}$ & $\begin{array}{l}\text { A dummy } \\
\text { variable for } \\
\text { working status }\end{array}$ & $\begin{array}{l}\text { A dummy variable for } \\
\text { diagnosed alcohol } \\
\text { dependence. }\end{array}$ & $\begin{array}{l}\text { Probit-model } \\
\text { and IV- } \\
\text { Probit }\end{array}$ & $\begin{array}{l}\text { Alcohol-dependent individuals have } \\
\text { lower employment probabilities. }\end{array}$ \\
\hline $\begin{array}{l}\text { Sloan, F. and } \\
\text { Grossman, D. } \\
2011 .\end{array}$ & $\begin{array}{l}\text { Data from 1982-1984 } \\
\text { National Longitudinal } \\
\text { Survey of Youth } \\
1979 .\end{array}$ & Annual earnings & $\begin{array}{l}5 \text { categories for alcohol } \\
\text { drinks consumed per week }\end{array}$ & OLS & $\begin{array}{l}\text { The relationship between heavy } \\
\text { drinking in early adulthood is } \\
\text { negatively associated with earnings } \\
\text { at midlife for black men. }\end{array}$ \\
\hline $\begin{array}{l}\text { Rose, R., } \\
\text { Winter, T., } \\
\text { Viken, R. and } \\
\text { Kaprio, J. } 2014 .\end{array}$ & Finnish twin data & $\begin{array}{l}\text { Self-reported } \\
\text { financial } \\
\text { situation } \\
\text { ranking from } 1 \\
\text { to } 5\end{array}$ & $\begin{array}{l}\text { Rutgers Alcohol Problem } \\
\text { Index }\end{array}$ & $\begin{array}{l}\text { Mean } \\
\text { difference } \\
\text { test }\end{array}$ & $\begin{array}{l}\text { Adolescent drinking predicts } \\
\text { difficulties in financial situation } \\
\text { later in life. }\end{array}$ \\
\hline $\begin{array}{l}\text { Paijärvi, T., } \\
\text { Martikainen, P., } \\
\text { Oensola, T., } \\
\text { Leinonen, T., } \\
\text { Herttua, K. abd } \\
\text { Mäkelä, P. } \\
2015 .\end{array}$ & $\begin{array}{l}\text { Register-based } 11 \% \\
\text { random sample of } \\
\text { Finnish individuals at } \\
\text { ages } 18-34 \text { linked to } \\
\text { the data of National } \\
\text { Institute for Health } \\
\text { and Welfare. }\end{array}$ & $\begin{array}{l}\text { Register-based } \\
\text { information on } \\
\text { employment }\end{array}$ & $\begin{array}{l}\text { Alcohol-related diagnoses } \\
\text { recorded in the Hospital } \\
\text { Discharge Register and the } \\
\text { Cause of Death Register as } \\
\text { proxy measure for problem } \\
\text { drinking. }\end{array}$ & $\begin{array}{l}\text { Generalized } \\
\text { estimating } \\
\text { equations }\end{array}$ & $\begin{array}{l}\text { Adolescent drinking is negatively } \\
\text { related to employment later in life. }\end{array}$ \\
\hline
\end{tabular}


Table II. Mean characteristics of the sample

\begin{tabular}{llll}
\hline & Mean & Std. & Source \\
\hline Individual characteristics $^{a}$ & & & \\
Female & 0.58 & 0.49 & FLEED \\
Education (years) & 11.3 & 2.15 & FLEED \\
Age & 45.9 & 5.22 & FLEED \\
Married & 0.53 & 0.34 & FLEED \\
Ever divorced & 0.16 & 0.34 & Twin surveys and FLEED \\
Underage children & 0.55 & 0.24 & FLEED \\
Long-term labor market outcomes & & & \\
Earnings (€) & 20,014 & 11,853 & FLEED \\
Employment months & 9.6 & 3.4 & FLEED \\
Alcohol consumption & & & \\
Former drinker & 0.06 & 0.25 & Twin surveys 1975, 1981 and 1990 \\
Constant abstainer & 0.07 & 0.25 & Twin surveys 1975, 1981 and 1990 \\
Moderate drinker & 0.82 & 0.39 & Twin survey 1990 \\
Heavy drinker & 0.05 & 0.22 & Twin survey 1990 \\
Binge drinker & 0.13 & 0.33 & Twin survey 1990 \\
Other variables & & & \\
Stressful life events index & 1.39 & 1.19 & Twin survey 1990 \\
Smoking, measured in pack-years & 6.6 & 11.0 & Twin survey 1990 \\
Number of diseases in 1975 & 0.54 & 0.81 & Twin survey 1975 \\
\hline
\end{tabular}

a: The means of individual characteristics (except gender) were measured over the period 19902009. 
Table III. Alcohol consumption, binge drinking and long-term labor market outcomes

\begin{tabular}{|c|c|c|c|}
\hline $\begin{array}{l}\text { Panel A: Alcohol } \\
\text { consumption }\end{array}$ & $\%$-Share & $\begin{array}{l}\text { Employment } \\
\text { months }\end{array}$ & $\begin{array}{l}\text { Lifetime } \\
\text { earnings }(€)\end{array}$ \\
\hline Former drinker & 6.4 & 8.92 & 15,296 \\
\hline Constant abstainer & 6.7 & 9.43 & 17,347 \\
\hline Moderate drinker & 81.8 & 9.68 & 20,702 \\
\hline Heavy drinker & 5.1 & 8.35 & 18,425 \\
\hline F-test statistics & & $\begin{array}{l}18.36 \\
(\mathrm{p}<0.001)\end{array}$ & $\begin{array}{l}34.19 \\
(\mathrm{p}<0.001)\end{array}$ \\
\hline Panel B: Binge drinking & $\%$-Share & $\begin{array}{l}\text { Employment } \\
\text { months }\end{array}$ & $\begin{array}{l}\text { Lifetime } \\
\text { earnings }(€)\end{array}$ \\
\hline Not binge drinker & 87.2 & 9.62 & 20,143 \\
\hline Binge drinker & 12.8 & 9.02 & 19,139 \\
\hline F-test statistics & & $\begin{array}{l}20.39 \\
(p<0.001)\end{array}$ & $\begin{array}{l}8.39 \\
(p<0.01)\end{array}$ \\
\hline Person-year observations & & 6610 & 6610 \\
\hline
\end{tabular}

Notes: Heteroscedasticity-robust F-test statistics for the null hypothesis of equal group means. 
Health Economics, forthcoming

Table IV. A cross-tabulation of alcohol consumption patterns within twin pairs $(\mathrm{N}=3305)$

\begin{tabular}{lcccc}
\hline & Former drinker & $\begin{array}{l}\text { Constant } \\
\text { abstainer }\end{array}$ & Moderate drinker & $\begin{array}{l}\text { Heavy } \\
\text { drinker }\end{array}$ \\
\hline Former drinker & $51(1.5 \%)$ & & & \\
Constant abstainer & $42(1.3 \%)$ & $101(3.1 \%)$ & & \\
Moderate drinker & $273(8.3 \%)$ & $190(5.7 \%)$ & $2340(70.8 \%)$ & \\
Heavy drinker & $7(0.2 \%)$ & $6(0.2 \%)$ & $262(7.9 \%)$ & $33(1.0 \%)$ \\
\hline
\end{tabular}




\section{Health Economics, forthcoming}

Table V. Alcohol consumption and long-term labor market outcomes

\begin{tabular}{|c|c|c|c|c|c|c|c|c|c|c|c|c|}
\hline \multirow[b]{2}{*}{ Employment } & \multicolumn{3}{|c|}{ OLS level: DZ and MZ } & \multicolumn{3}{|c|}{ Twin differences: DZ and MZ } & \multicolumn{3}{|c|}{ Twin differences: DZ } & \multicolumn{3}{|c|}{ Twin differences: MZ } \\
\hline & $\beta$ & $95 \% \mathrm{CI}$ & & $\beta$ & $95 \%$ & & $\beta$ & $95 \% \mathrm{CI}$ & & $\beta$ & $95 \%$ & \\
\hline \multicolumn{13}{|l|}{ Alcohol use } \\
\hline Former drinker & $\begin{array}{l}-0.595 * * * \\
(0.195)\end{array}$ & -0.978 & -0.212 & $\begin{array}{l}-0.839 * * \\
(0.253)\end{array}$ & -1.335 & -0.343 & $\begin{array}{l}-0.757 * * \\
(0.322)\end{array}$ & -1.389 & -0.126 & $\begin{array}{l}-0.940 * * \\
(0.340)\end{array}$ & -1.715 & -0.164 \\
\hline Constant abstainer & $\begin{array}{c}0.037 \\
(0.186)\end{array}$ & -0.328 & 0.402 & $\begin{array}{l}-0.105 \\
(0.297)\end{array}$ & -0.687 & 0.477 & $\begin{array}{l}-0.410 \\
(0.350)\end{array}$ & -1.096 & 0.276 & $\begin{array}{c}0.649 \\
(0.552)\end{array}$ & -0.435 & 1.732 \\
\hline Heavy drinker & $\begin{array}{l}-1.467 * * * \\
(0.229)\end{array}$ & -1.917 & -1.017 & $\begin{array}{l}-1.124 * * * \\
(0.283)\end{array}$ & -1.679 & -0.570 & $\begin{array}{l}-1.275 * * * \\
(0.348)\end{array}$ & -1.957 & -0.593 & $\begin{array}{l}-0.818 * \\
(0.486)\end{array}$ & -1.771 & 0.135 \\
\hline
\end{tabular}

Log(earnings)

Alcohol use

\begin{tabular}{|c|c|c|c|c|c|c|c|c|c|c|c|c|}
\hline Former drinker & $\begin{array}{l}-0.322 * * * \\
(0.055)\end{array}$ & -0.431 & -0.213 & $\begin{array}{l}-0.283 * * * \\
(0.069)\end{array}$ & -0.419 & -0.147 & $\begin{array}{l}-0.318 * * * \\
(0.088)\end{array}$ & -0.491 & -0.146 & $\begin{array}{l}-0.198 * \\
(0.107)\end{array}$ & -0.408 & 0.013 \\
\hline Constant abstainer & $\begin{array}{l}-0.146 * * * \\
(0.051)\end{array}$ & -0.247 & -0.045 & $\begin{array}{l}-0.192 * * \\
(0.079)\end{array}$ & -0.347 & -0.037 & $\begin{array}{l}-0.241 * * \\
(0.096)\end{array}$ & -0.429 & -0.052 & $\begin{array}{l}-0.057 \\
(0.133)\end{array}$ & -0.318 & 0.204 \\
\hline Heavy drinker & $\begin{array}{l}-0.363 * * * \\
(0.063)\end{array}$ & -0.486 & -0.239 & $\begin{array}{l}-0.342 * * * \\
(0.070)\end{array}$ & -0.478 & -0.205 & $\begin{array}{l}-0.424 * * * \\
(0.091)\end{array}$ & -0.603 & -0.246 & $\begin{array}{l}-0.180 * \\
(0.103)\end{array}$ & -0.383 & 0.022 \\
\hline
\end{tabular}

$\mathrm{N}$

6610

3305

2104

1201

Notes: $\mathrm{MZ}=$ monozygotic; DZ = dizygotic. Heteroscedasticity-robust standard errors are in parenthesis. Reference category: moderate drinkers. OLS level models include controls for gender, and age and its square. $* * *, * *, *$ : statistically significant at least at the $1 \%, 5 \%$ and $10 \%$ levels, respectively. 


\section{Health Economics, forthcoming}

Table VI. Within MZ-regressions on alcohol consumption and long-term labor market outcomes by gender

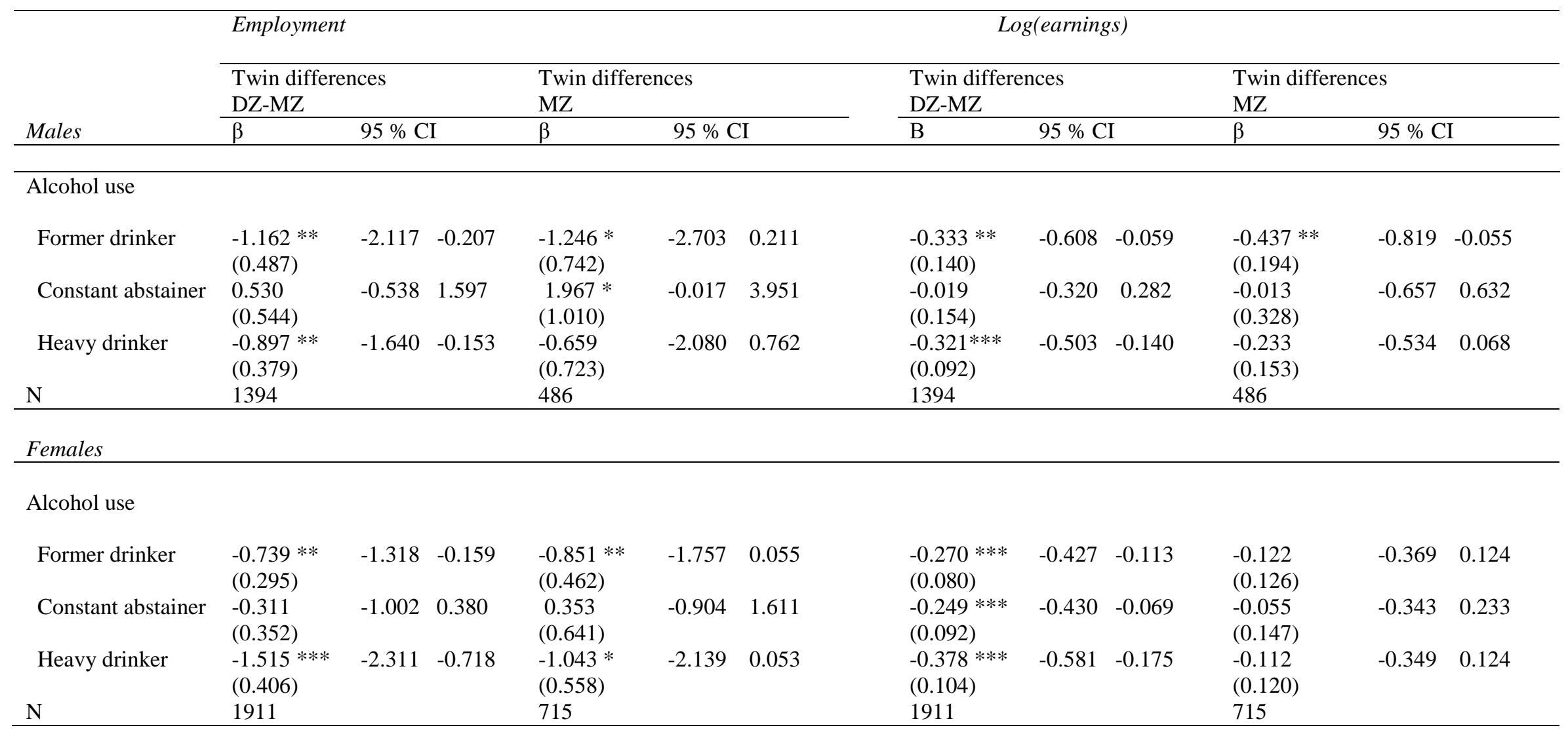

Notes: $\mathrm{MZ}=$ monozygotic; $\mathrm{DZ}=$ dizygotic. Heteroscedasticity-robust standard errors are in parenthesis. Reference category: moderate drinkers. $* * *, * *$, *: statistically significant at least at the $1 \%, 5 \%$ and $10 \%$ levels, respectively. 


\section{Health Economics, forthcoming}

Table VII. Within MZ-regressions on alcohol consumption and long-term labor market outcomes with additional control/mediator variables

\begin{tabular}{|c|c|c|c|c|c|c|}
\hline & \multicolumn{3}{|c|}{ Employment } & \multicolumn{3}{|c|}{ Log(earnings) } \\
\hline & \multicolumn{3}{|c|}{$\begin{array}{l}\text { Twin differences } \\
\mathrm{MZ}\end{array}$} & \multicolumn{3}{|c|}{$\begin{array}{l}\text { Twin differences } \\
\text { MZ }\end{array}$} \\
\hline & $\beta$ & \multicolumn{2}{|c|}{$95 \% \mathrm{CI}$} & $\beta$ & \multicolumn{2}{|c|}{$95 \% \mathrm{CI}$} \\
\hline \multicolumn{7}{|l|}{ Alcohol use } \\
\hline Former drinker & $\begin{array}{l}-0.930 * * \\
(0.397)\end{array}$ & -1.708 & -0.151 & $\begin{array}{l}-0.207 * \\
(0.106)\end{array}$ & -0.415 & 0.002 \\
\hline Constant abstainer & $\begin{array}{c}0.545 \\
(0.544)\end{array}$ & -0.522 & 1.611 & $\begin{array}{l}-0.066 \\
(0.135)\end{array}$ & -0.330 & 0.199 \\
\hline Heavy drinker & $\begin{array}{l}-0.747 \\
(0.484)\end{array}$ & -1.697 & 0.203 & $\begin{array}{l}-0.170 * \\
(0.100)\end{array}$ & -0.367 & 0.026 \\
\hline Additional controls included & YES & & & YES & & \\
\hline $\mathrm{N}$ & 1201 & & & 1201 & & \\
\hline
\end{tabular}

Notes: $\mathrm{MZ}=$ monozygotic; $\mathrm{DZ}=$ dizygotic. Heteroscedasticity-robust standard errors are in parenthesis. Reference category: moderate drinkers. $* * *, * *, *$ : statistically significant at least at the $1 \%, 5 \%$ and $10 \%$ levels, respectively. Additional controls are education years, number of diseases (in 1975), smoking and SLE index. 


\section{Health Economics, forthcoming}

Table VIII. Within MZ-regressions on alcohol consumption and long-term labor market outcomes using different alcohol measures: bivariate regressions

\begin{tabular}{|c|c|c|c|c|c|c|}
\hline & \multicolumn{3}{|c|}{ Employment months } & \multicolumn{3}{|c|}{ Log(earnings) } \\
\hline & \multicolumn{3}{|c|}{$\begin{array}{l}\text { Twin differences } \\
\mathrm{MZ}\end{array}$} & \multicolumn{3}{|c|}{$\begin{array}{l}\text { Twin differences } \\
\mathrm{MZ}\end{array}$} \\
\hline & $\beta$ & \multicolumn{2}{|c|}{$95 \% \mathrm{CI}$} & $\beta$ & \multicolumn{2}{|c|}{$95 \% \mathrm{CI}$} \\
\hline \multicolumn{7}{|c|}{ 1) Alcohol use with lower thresholds } \\
\hline Former drinker & $\begin{array}{l}-0.935 * * \\
(0.395)\end{array}$ & -1.701 & -0.160 & $\begin{array}{l}-0.199 * \\
(0.107)\end{array}$ & -0.409 & 0.011 \\
\hline Constant abstainer & $\begin{array}{c}0.647 \\
(0.551)\end{array}$ & -0.433 & 1.727 & $\begin{array}{l}-0.063 \\
(0.132)\end{array}$ & -0.322 & 0.197 \\
\hline Heavy drinker & $\begin{array}{l}-0.531 \\
(0.341)\end{array}$ & -1.200 & 0.137 & $\begin{array}{l}-0.179 * * * \\
(0.067)\end{array}$ & -0.311 & -0.048 \\
\hline 2) Binge drinker & $\begin{array}{l}-0.802 * * * \\
(0.266)\end{array}$ & -1.324 & -0.281 & $\begin{array}{l}-0.096 * \\
(0.058)\end{array}$ & -0.209 & 0.017 \\
\hline \multicolumn{7}{|c|}{$\begin{array}{l}\text { 3) Alcohol use and binge drinking in the } \\
\text { same model }\end{array}$} \\
\hline Former drinker & $\begin{array}{l}-0.961 * * \\
(0.395)\end{array}$ & -1.735 & -0.186 & $\begin{array}{l}-0.200 * \\
(0.107)\end{array}$ & -0.411 & 0.010 \\
\hline Constant abstainer & $\begin{array}{l}0.638 \\
(0.551)\end{array}$ & -0.433 & 1.718 & $\begin{array}{l}-0.058 \\
(0.134)\end{array}$ & -0.320 & 0.204 \\
\hline Heavy drinker & $\begin{array}{l}-0.683 \\
(0.484)\end{array}$ & -1.632 & 0.266 & $\begin{array}{l}-0.165 \\
(0.101)\end{array}$ & -0.363 & 0.033 \\
\hline Binge drinker & $\begin{array}{l}-0.752 * * * \\
(0.267)\end{array}$ & -1.276 & -0.227 & $\begin{array}{l}-0.085 \\
(0.055)\end{array}$ & -0.193 & 0.024 \\
\hline $\mathrm{N}$ & 1201 & & & 1201 & & \\
\hline
\end{tabular}

Notes: $\mathrm{MZ}=$ monozygotic. Heteroscedasticity-robust standard errors are in parenthesis. ***, **, *: statistically significant at least at the $1 \%, 5 \%$ and $10 \%$ levels, respectively. 